\title{
PENGEMBANGAN USAHA KELOMPOK PRODUSEN DADIH DI KECAMATAN TILATANG KAMANG
}

\author{
Amna Suresti, Salam N. Aritonang, Rahmi Wati \\ Fakultas Peternakan Universitas Andalas \\ amnareres@yahoo.com
}

Received: 25 Juni 2018. Accepted: 01 Agustus 2018. Published Online 10 September 2018

\begin{abstract}
ABSTRAK
Kegiatan ini bertujuan untuk: 1) meningkatkan motivasi wirausaha mitra; 2) meningkatkan wawasan dan pengetahuan tentang manajemen pemeliharaan ternak kerbau; 3) meningkatkan kemampuan mitra dalam mendiversifikasi dadih menjadi beberapa produk serta 4) mengembangkan wilayah pemasaran. Hasil dari kegiatan ini diantaranya adalah: 1) meningkatkan jiwa entrepreneurship mitra sebagai upaya menunjang kegiatan pengembangan kelompok; 2) Kegiatan penyuluhan manajemen pemeliharaan ternak kerbau mampu meningkatkan wawasan dan pengetahuan peternak dalam memelihara ternak kerbau; 3). Pelatihan dan percontohan diversifikasi dadih mampu meningkatkan pendapatan dan 4) Kegiatan promosi dan pengembangan jaringan pemasaran telah dijadikan sebagai strategi pemasaran untuk meningkatkan volume produksi kelompok usaha.
\end{abstract}

Kata Kunci : pelatihan, pembinaan, pendampingan, produsen dadih.

\section{Business Development of Dadih Manufacturer Group in Tilatang Kamang District}

\begin{abstract}
This article describes the results of the community service activities for training, coaching and mentoring on producer dadih groups in the District Tilatang Kamang. This activity aims to: 1) increase the motivation of entrepreneurial partners; 2) increase the insight and knowledge of maintenance management buffaloes; 3 ) improve the ability of the partners to diversify into multiple product dadih and 4) developing the marketing area. The results of this activity are: 1) increase the entrepreneurial spirit partner as efforts to support the development of the group; 2) Activity buffaloes maintenance management counseling can improve insight and knowledge in raising livestock breeder buffalo; 3) Training and the pilot was able to increase revenue diversification dadih and 4) The promotion and development of network marketing has been used as a marketing strategy to increase the production volume of business groups.
\end{abstract}

Keywords: training, coaching, mentoring, manufacturers of dadih.

\section{PENDAHULUAN}

Proses pembuatan dadih dari susu kerbau dalam tabung bambu, telah lama dikenal oleh masyarakat di Kabupaten ini, namun informasi tentang potensi dadih sebagai sumber pendapatan peternak belum diketahui. Sebagai makanan tradisional ternyata dadih ini mempunyai khasiat ganda yaitu sebagai gizi, kesehatan dan makanan budaya.Pada umumnya dadih dimanfaatkan sebagai lauk pauk, makanan selingan, pelengkap upacara adat dan sebagai obat-obatan tradisionat. Untuk dapat mengembangkan produk dadih ini harus didukung dengan suatu standar teknologi pengolahan dan standar hasil produk olahan. Karena itu keberadaan dadih perlu dukungan sehingga pengembangannya bisa diterima masyarakat luas. 
Usaha pembuatan dadih di daerah ini sudah dilakukan secara turun temurun namun jika dilihat dari kualitas usahanya dapat disimpulkan bahwa pembuatan dadih didaerah ini tidak mengalami kemajuan yang berarti baik dari jumlah pelaku usaha maupun dari sisi pemasaran. Manajemen usaha dadih ini belum memperlihathatkan bagaimana cara meningkatkan kualitas dan olahan dadih nyang lebih baik, begitu juga dengan harga yang diperoleh oleh mitra terlalu kecil dan kadangkala hargapun dipermainkan oleh pedagang perantara hal ini dikarenakan tidak adanya lembaga atau kelompok yang mengusahakan usaha ini dapat berorientasi bisnis sehingga diharapkan dapat meningkatkan pendapatan peternak. Dari sudut pandang konsep pemasaran terlihat bahwa dadih yang dihasilkan masih bersifat generik, dimana belum ada dilakukan usaha untuk menambah nilai/value yang dilakukan oleh produsen, bahkan usaha pengolahan dadih menjadi bentuk makan yang lain tidak dilakukan oleh produsen didaerah ini. dadih yang dijual oleh mitra masih berupa dadih murni yang dijual ke pasar terdekat, belum adanya tersentuh dengan tekhnologi diversifikasi produk. Disamping itu usaha dari produsen untuk memperkenalkan dadih ini hanya terbatas pada daerah sekitar namun diluar daerah mereka belum lakukan. Mitra juga mengalami kesulitan dalam mengolah dadih dalam bentuk makanan lain yang disukai oleh konsumen seperti rasa dan aromanya.

Di Kecamatan Tilatang Kamang ini hanya ada 14 orang dari jumlah rumah tangga peternak yang mengusahakan pengolahan susu kerbau menjadi dadih, yaitu 3 orang di nagari Kapau, 6 orang di Gadut dan 5 orang dinagari Koto tangah. Rata-rata kepemilikkan kerbau per orang hanya berkisar antara $1-2$ ekor dengan produksi dadih dapat menghasilkan sekitar 15 tabung (1 tabung isi $200 \mathrm{ml}$ susu). Kalau kita lihat produksi rata-rata susu perhari dari 14 produsen diatas, maka secara keseluruhan produksi dadih di Kecamatan Tilatang Kamang ini rata-rata 120 tabung/hari yang dijual di Pasar Atas dan Pasar Bawah Bukittinggi. Harga per tabung Rp.5000 yang dijual kepedagang perantara, sementara harga jual dipasar oleh pedagang perantara berkisar antara Rp.7000 sampai Rp.8000 per tabung. Pendapatan yang diterima oleh peternak dari penjualan dadih ini berkisar antara Rp 20.000 sampai Rp.35.000 setiap hari. Pendapatan peternak sebenarnya masih dapat ditingkatkan lagi jika petani pemilik kerbau penghasil dadih tersebut mau membuka diri untuk menerima inovasi baru, baik di bidang produksi dengan meningkatkan skala usaha ternak kerbau yang dipeliharanya, maupun teknologi dalam pembuatan produk dari dadih.

Rendahnya produksi susu salah satu diakibatkan minimnya pemahaman dan ketrampilan peternak dalam memelihara ternak kerbau. Usaha ini juga tidak terlepas dari manajemen pemeliharaan ternak kerbau, dimana pola pemeliharaan masih bersifat tradisional sebagai warisan dari orang tua. Manajemen pemeliharaan ternak khususnya untuk pakan, hanya mengandalkan ketersediaan rumput alam yang selalu mengalami keterbatasan, baik dalam jumlah dan mutu. Peternak juga belum menggunakan konsentrat sebagai suplemen untuk peningkatan produksi susu. Melihat tatalaksana pemeliharaan yang sederhana dan belum mengenal pemberian makanan tambahan berupa konsentrat, bukanlah hal yang tidak mungkin untuk meningkatkan produksi susu kerbau di kedua daerah tersebut. Walaupun hanya dengan pakan yang sangat sederhana hanya berupa hijauan lapangan yang mempunyai nilai nutrisi relatif rendah sangat wajar jika produksinya hanya sedemikian saja. Perbaikan managemen masih bisa ditingkatkan melalui usaha perbaikan pengelolaan dan perkandangan serta tata cara pemeliharaan sehingga kehilangan energy sewaktu degembalakan atau sewaktu merumput dapat dieliminir menjadi keperluan produksi susu. 
Walaupun Usaha pembuatan dadih di daerah ini sudah dilakukan secara turun temurun namun jika dilihat dari kualitas usahanya dapat disimpulkan bahwa pembuatan dadih didaerah ini tidak mengalami kemajuan yang berarti baik dari jumlah pelaku usaha maupun dari sisi pemasaran. manajemen usaha dadih ini belum memperlihatkan bagaimana cara meningkatkan kualitas dan olahan dadih yang lebih baik, begitu juga dengan harga yang diperoleh oleh mitra terlalu kecil dan kadangkala hargapun dipermainkan oleh pedagang perantara hal ini dikarenakan tidak adanya lembaga atau kelompok yang mengusahakan usaha ini dapat berorientasi bisnis sehingga diharapkan dapat meningkatkan pendapatan peternak. Dari sudut pandang konsep pemasaran terlihat bahwa dadih yang dihasilkan masih bersifat generik, dimana belum ada dilakukan usaha untuk menambah nilai/value yang dilakukan oleh produsen., bahkan usaha pengolahan dadih menjadi bentuk makan yang lain tidak dilakukan oleh produsen didaerah ini. dadih yang dijual oleh mitra masih berupa dadih murni yang dijual ke pasar terdekat, belum adanya tersentuh dengan tekhnologi diversifikasi produk. Disamping itu usaha dari produsen untuk memperkenalkan dadih ini hanya terbatas pada daerah sekitar namun diluar daerah mereka belum lakukan. mitra juga mengalami kesulitan dalam mengolah dadih dalam bentuk makanan lain yang disukai oleh konsumen seperti rasa dan aromanya.

Dari analisis awal dengan kelompok dapat beberapa persoalan yang dihadapi oleh kelompok diantaranya adalah rendahnya produksi susu, lemahnya teknologi pascapanen yang dimiliki oleh kelompok, manajemen usaha yang belum terarah lebih baik serta pasar yang kurang menjanjikan dari tahun ke tahun tampak dengan tidak berkembangnya perluasan pasar, sehingga pendapatan peternak dari tahun ketahun tidak ada peningkatan. Selain itu rasa dan aroma dadih juga kurang diminati oleh konsumen kalangan muda. Hanya masyarakat yang berusia 45 tahun keatas yang banyak mengkonsumsi dadih. Di luar itu alasan bahwa masyarakat kurang menyenangi dadih karena aroma yang dikeluarkan dari dadih kurang disenangi oleh masyarakat. Untuk itu kelompok ini ingin membuat dadih yang disukai oleh masyarakat yang berusia dibawah 45 th khususnya anak-anak sekolah, tetapi terkendala dengan ketidaktahuan dan ketidak mampuan dalam mendiversifikasi produk. Disamping itu untuk memperluas pasar, kelompok ini juga berkeinginan untuk mempromosikan usahanya diluar daerah tetapi juga mereka tidak tahu bagaimana caranya mempromosikan usaha ini keluar dareah. Kendala lain yang lebih penting adalah motivasi mitra sangat rendah untuk mengembangkan usaha lebih besar lagi karena keterbatasan pengetahuan dan ketrampilan.

Begitu juga dengan konsumen yang berada di luar kabupaten Agam ini seperti Padang, Pariaman, Pasaman dan lain-lain, minat masyarakat terhadap dadih masih kurang padahal fungsi dadih sangat bagus untuk kesehatan tubuh. Rendahnya pengetahuan dan ketrampilan mitra untuk meningkatkan pendapatan melalui usaha ini masih rendah sehingga motivasi berwirausahapun juga rendah, padahal kita tahu bahwa nilai gizi dadih sangat baik untuk kesehatan. Dengan melihat keadaan diatas, kondisi dadih sangat memprihatinkan dan perlu untuk dilestarikan. Keadaan ini diperparah lagi dengan makin kurangnya produksi dadih, populasi kerbau semakin menyusut, minat dan perhatian pemerintah yang kurang mendukung dapat mengakibatkan dadih makin lama makin hilang dan tidak dikenal lagi oleh generasi penerus. Maka dari itu dadih sangat perlu untuk dipertahankan dan dilestarikan sebagai makanan khas Sumatera Barat.

Akibatnya pendapatan yang diterima dari usaha ini tidak pernah mengalami peningkatan, dimana kisaran pendapatan yang diterima perhari sebesar Rp 20.000,- 
sampai Rp 30.000,-/hari. Diharapkan dari penggunaan teknologi yang ditawarkan kepada kedua kelompok. akan meningkatkan pendapatan sekitar $70 \%$ dari rata-rata pendapatan yang diterima sebelumnya.

Dari identifikasi permasalahan di atas maka dapat di ambil kendala-kendala yang menjadi permasalahan utama dalam produksi, perluasan pasar dan aroma dadih yang tidak disukai oleh masyarakat sebagai berikut : 1.motivasi mitra sangat rendah untuk mengembangkan usaha menjadi lebih besar. Disebabkan karena keterbatasan pengetahuan dan ketrampilan, 2. Produksi susu kerbau masih rendah berkisar 12liter/ekor/hari, sementara produksi susu ideal adalah $3-5$ liter/ekor/hari. karena pemeliharaan kerbau belum mengenal sistem manajemen produksi ternak yang tepat, sehingga berdampak terhadap produksi dadih yang dihaslkan, 3. Belum ada pemikiran dari peternak untuk mendiversifikasi produknya dengan menggunakan teknologi penghilang aroma dadih dan teknologi pembuatan dan diversivikasi dadih menjadi produk lain (es dadih, dadih dengan aroma baru/tape). serta teknologi kemasan dari bentuk tabung bambu menjadi kemasan dadih dengan cup plastic atau yang lainnya, dan 4. Manajemen pemasaran masih kurang baik, belum menerapkan konsep manajamen pemasaran yang strategis. Diperlukan perbaikan dalam produk dan kemasan serta promosi agar bisa meningkatkan performan dari produk memperluas pasar. Belum adanya jaringan pemasaran yang lebih jauh untuk memasarkan produk. Perlu diupayakan sarana dan prasarana untuk menunjang pemasaran produk yang dihasilkan untuk memperluas pasar.Belum adanya kegiatan promosi untuk memperkenalkan produk kepada konsumen.

Sedangkan tujuan kegiatan ini adalah : 1. Meningkatkan motivasi wirausaha mitra, 2. Meningkatkan wawasan dan pengetahuan tentang manajemen pemeliharaan ternak kerbau, 3. meningkatkan kemampuan mitra dalam mendiversifikasi dadih menjadi beberapa produk dan 4 . mengembangkan pemasaran dengan perbaikan kemasan.

\section{METODE}

Metode yang digunakan untuk pemecahan masalah pada usaha mitra adalah perbaikan manajemen pemeliharaan ternak sapi perah, diversivikasi produk susu, perancangan kemasan serta perancangan penambahan jalur distribusi baru. Metode yang digunakan adalah:

\section{a. Metode Penyuluhan}

Penyuluhan dilakukan kepada peternak kerbau dan pengusaha dadih yang berada di dua Jorong yaitu Jorong Pincuran dan Jorong Barangin. Pada penyuluhan ini melibatkan sebanyak 25 orang peternak dan pengusaha dadih (mitra) juga mendapatkan kesempatan untuk dapat menyampaikan gagasan - gagasan yang ingin mereka kemukakan.

Dalam penyuluhan ini materi yang akan diberikan adalah:

1. Penyuluhan kewirausahaan. Materi ini perlu untuk disampaikan untuk memotivasi mitra agar dapat meningkatkan produksinya dalam upaya untuk meningkatkan pendapatan serta dapat memberikan informasi pasar untuk perluasan pasar dan pembuatan bisnis plan.

2. Memberikan penyuluhan tentang manajemen produksi susu ternak kerbau untuk meningkatkan produksi dadih. 
3. memberikan penyuluhan tentang manajemen pemasaran dadih mengenai bauran pemasaran yang meliputi strategi produk, tempat, harga dan promosi

4. Memberikan penyuluhan tentang teknologi pembuatan diversivikasi dadih menjadi produk lain (es dadih, dadih dengan aroma baru/tape). Selain itu juga penyuluhan tentang pembuatan kemasan dadih yang lebih baik dan higienis serta dapat didistribusikan pada pasar - pasar modern sehingga lebih dikenal oleh masyarakat luas.

\section{b. Pelatihan dan Percontohan}

Pada kegiatan ini diperagakan atau didemonstrasikan bagaimana teknologi diversivikasi pengolahan dadih menjadi produk lainseperti pembuatan es dadih dan dadih dengan aroma baru/tape. Selain itu juga pembuatan kemasan yang lebih baik dan higienis. Kegiatan demonstrasi dilanjutkan dengan pelatihan pada masyarakat. Pada saat pelatihan atau percontohan dilakukan mitra diikutsertakan secara aktif melalui diskusi-diskusi dan konsultasi tentang pelaksanaan kegiatan dan penerapan teknologi yang diberikan serta kendala-kendala yang dihadapi, untuk lebih memaksimalkan hasil kegiatan ini.

\section{c. Perluasan Pasar}

Untuk meningkatkan penjualan maka diupayakan untuk memperluas distribusi dengan merancang perluasan pasar. Dengan diversivikasi produk yang telah dilakukan maka pemasaran dapat diperluas dari mulai anak-anak sampai ke pada orang tua. Belum ada teknologi promosi dari daerah setempat dalam memperkenalkan dadih, untuk itu perlu dirancang pembuatan iklan di Koran, plang nama, dan brosur yang disediakan untuk mempromosikan dadih ini di kota lain untuk memperluas pasar.

\section{HASIL DAN PEMBAHASAN}

\section{Persiapan Kegiatan}

Kegiatan yang direncanakan sebelumnya akan dilakukan dilakukan pada kedua kelompok produsen dadih yaitu di kelompok baringin dan pincuran, namun setelah proposal disetujui, kami melakukan peninjauan ulang atau memverifikasi kondisi usaha mitra. Namun kedua kelompok telah menjual ternaknya sehingga tidak berproduksi dadih lagi, sehingga dengan kesepakatan wali jorong setempat dialihkan pada kelompok jorong PGRM dan jorong Koto Tangah yang mempunyai permasalahan yang sama. Setelah dilakukan peninjauan ke lokasi mitra diperoleh informasi bahwa kedua mitra sangat membutuhkan teknologi yang akan kami berikan. Anggota kelompok berkurang jumlahnya dan motivasi berwirausaha dari anggota kelompok juga menurun, peternak cenderung menjual ternak kerbau mereka. Sehingga saat sekarang ini anggota yang masih bertahan hanya 3 sampai 6 orang.

Setelah diketahui kebutuhan permasalahan dan kebutuhan mitra maka selanjutnya dilakukan persiapan pelaksanaan kegiatan. Kami merencanakan langkah - langkah yang akan dilakukan. Diantaranya adalah persiapan penyuluhan, metode pembuatan produk olahan lain dari susu. Kegiatan penyuluhan dilakukan untuk memotivasi peternak dan perbaikan manajemen pemeliharaan peternak kerbau. Selain itu kami juga melakukan kegiatan pelatihan dan percontohan pembuatan beberapa olahan dadih berupa esdadih, 
pudding, sauce dan jus dadih. Mitra juga terkendala dengan perluasan pasar dadih dan olhannya. untuk pembuatan olahan dadih ini kami merencanakan untuk membantu pengadaan alat-alat berupa kulkas, blender termos es, dan etalase. Begitu juga dengan permasalahan pemasaran, khususnya kemasan pudding kami menawarkan dengan labeling dan brosur. Selain itu untuk mempermudah pemasaran kami juga mempersiapkan 2 buah etalase sebagai wadah untuk memajang produk.

\section{Pelaksanaan Kegiatan.}

\section{Kegiatan Penyuluhan}

Kegiatan penyuluhan yang pertama kali kami lakukan adalah pemahaman peternak tentang kelompok produsen dadih, tujuan kelompok dan aktifitas dalam kelompok. Seperti halnya kelompok usaha kecil dan menengah, faktor individu masih dianggap menonjol dalam mementukan model kelembagaan dan pengaturan personalia. Walaupun jumlah anggota ada 10 orang, tetapi hanya 4 orang yang dianggap mengendalikan usaha ini. Pembagian tugas didasarkan kepada kemampuan masingmasing. Namun dengan kemampuan yang dimiliki oleh 4 orang ini, proses produksi bisa dikuasai. Selama kegiatan berlangsung, dilakukan rasionalisasi tugas dan tanggung jawab masing-masing personil agar proses produksi bisa lebih baik. Serta dirancang model tugas pekerjaan yang dapat dilakukan oleh setiap personil bahkan bagi siapapun yang terlibat dalam proses produksi secara tentatif sesuai kebutuhan. Hal ini penting dilakukan agar proses produksi terjamin kualitasnya. Dari hasil diskusi, anggota sangat antusias untuk meningkatkan usaha olahan dadih ini dan telah berusaha untuk mencari tempat untuk usaha ini

Disamping itu, dari hasil pengamatan dilapangan, motivasi anggota untuk meningkatkan usaha mereka sangat rendah disebabkan karena keterbatasan pengetahuan dan ketrampilan mereka, akibatnya pendapatan mereka juga tidak bertambah. Kemudian penyuluhan berikutnya mengenai manajemen pemeliharaan kerbau, dimana persepsi dan pengetahuan peternak kerbau masih sangat rendah. Hal ini dapat diketahui dari hasil pengamatan dilapangan dan hasil brainstorming dengan anggota kelompok kedua mitra. Materi penyuluhan yang diberikan adalah:

a. Wirausaha, dimana matei ini bertujuan untuk memberikan motivasi kepada para peternak.

b. Manajemen pemeliharaan ternak kerbau.

Materi yang diiberikan antara lain adalah teknis pemeliharaan mulai dari metode pemeliharaan, penanganan kerbau, pakan dan jenis pakan yang diberikan, penanganan penyakit dan proses pemerahan yang higienis.

c. Recording usaha ternak kerbau yang meliputi performan reproduksi (angka kelahiran, calving interval, service per conseption); performans

d. Metode pengolahan susu. Mitra diberikan materi tentang metode pembuatan olahan dadih

\section{A. Motivasi Berwirausaha}

Materi motivasi berwirausaha diberikan oleh ibu Rahmi Wati, S.Pt,M.Si.. Materi ini perlu diberikan pada kegiatan penyuluhan, mengingat semangat anggota kelompok untuk mengembangkan usaha peternakan kerbau mulai menurun.. Selain itu para peternak mitra tidak punya pengetahuan dalam meningkatkan nilai tambah produk agar bisnisnya lebih menguntungkan. 
Motivasi adalah suatu faktor yang mendorong seseorang untuk melakukan sesuatu perbuatan atau kegiatan tertentu, sehingga motivasi dapat diartikan sebagai pendorong perilaku seseorang. Motivasi orang melakukan bisnis, wirausaha sering berbeda. Keanekaragaman ini menyebabkan perbedaan dalam perilaku yang berkaitan dengan kebutuhan dan tujuan.

Menjalankan sebuah usaha memang membutuhkan semangat dan tekad yang cukup kuat. Tanpa adanya motivasi dan semangat dari para pelakunya, bisa jadi usaha yang dijalankan tidak dapat mencapai puncak kesuksesan. Faktor inilah yang perlu diperhatikan para pelaku usaha, sebab hadirnya motivasi bisnis menjadi modal awal bagi mereka untuk merintis kesuksesan bisnisnya.

Untuk meningkatkan modal motivasi dalam diri pelaku usaha, menurut (Rahmi, 2014) berikut ini ada 4 motivasi sukses dalam menjalankan bisnis yang perlu Anda terapkan dari sekarang.

Pertama, tanamkan keinginan kuat untuk menambah pengetahuan dan kemampuan. Salah satu motivasi yang paling dibutuhkan pelaku usaha adalah keinginannya untuk terus belajar dan menambah keterampilan. Seperti kita ketahui bersama, motivasi belajar menjadi modal awal bagi para pengusaha untuk mengembangkan raksasa bisnisnya. Karena itu, belajarlah dari orang-orang sukses di sekitar Anda, belajarlah dari kegagalan yang pernah Anda alami, dan belajarlah dari sumber ilmu yang tersedia di seluruh belahan dunia.

Kedua, berani mengubah tantangan menjadi sebuah peluang. Jika sebagian orang menghindari sebuah resiko, maka lain halnya dengan para pengusaha yang memandang sebuah resiko sebagai peluang baru. Tidaklah heran bila selama ini banyak pelaku usaha yang sukses menemukan ide bisnis baru dari permasalahan kecil yang mereka hadapi setiap harinya. Misalnya saja seperti peluang bisnis jasa laundry yang diangkat dari permasalahan masyarakat di daerah perkotaan yang cenderung memiliki tingkat kesibukan cukup tinggi, sehingga mereka membutuhkan jasa cuci atau laundry sebagai solusi untuk mempermudah rutinitas mereka sehari-hari.

Ketiga, berusaha menjadi nomor satu. Sebagai seorang pelaku usaha, pastinya Anda dituntut untuk siap bersaing dan berusaha menduduki posisi pertama di setiap kesempatan. Dengan dorongan tersebut, para pelaku usaha termotivasi untuk terus berprestasi, meningkatkan produktifitasnya dan menciptakan inovasi baru untuk menghadapi persaingan bisnis yang semakin hari semakin sengit.

Keempat, tebal muka dan bermental baja. Tak jarang para pelaku usaha harus banting tulang dan bekerja keras untuk merintis sebuah usaha. Bahkan terkadang mereka harus turun langsung ke lapangan untuk menawarkan produk-produk unggulannya dari satu rumah ke rumah konsumen lainnya. Kondisi inilah yang menuntut para pelaku usaha untuk memiliki mental baja dan tidak mudah menyerah dengan kendala yang menghadang di tengah jalannya usaha.

Dengan memiliki motivasi bisnis seperti di atas, diharapkan para peternak mitra bisa mengembangkan bisnisnya lebih pesat dan mendapatkan untung berlipat-lipat tiap bulannya. Pemberian materi motivasi ini mampu membangkitkan kembali semangat para peternak untuk lebih giat lagi dalam mengembangkan usahanya.

\section{B. Manajemen Pemeliharaan Ternak Kerbau}

Faktor terpenting untuk sukses dalam usaha peternakan kerbau adalah peternak harus dapat menggabungkan kemampuan tata laksana yang baik dengan menentukan lokasi peternakan yang baik, besarnya peternakan, pemilihan berproduksi tinggi, 
pemakaian peralatan yang tepat, tanah yang subur untuk tanaman hijauan makanan ternak dan pemasaran yang baik (Sudono 1999).

Keberhasilan usaha peternakan kerbau sangat bergantung pada keterpaduan langkah terutama di bidang pembibitan (breeding), pakan (feeding), dan tata laksana (management). Manajemen peternakan sapi perah terdiri atas manajemen pemeliharaan, manajemen kandang, manajemen kesehatan, manajemen pemerahan pasca panen, manajemen reproduksi, dan manajemen pemasaran (Nurdin 2011).

Peternak pada kedua mitra ini memberikan pakan untuk kerbau hanya berupa hijauan saja dan tidak pernah menambahkan dengan konsentrat. Untuk itu melalui kegiatan ini kami memberikan penyuluhan tentang manajemen pemeliharaan kerbau terutama dalam hal pakan dan sanitasi kandang guna menunjang produksi susu. produksi susu kerbau yang dipelihara dengan pola kebiasaan petani memberikan pakan tambahan pada induk yang sedang laktasi (tradisional) dengan penambahan pakan $3 \mathrm{~kg}$ dedak padi hanya menghasilkan 0,8 1/ekor/hari, sedangkan pada pola petani yang diperbaiki dengan penambahan suplemen $2 \mathrm{~kg}$ dedak dan $1 \mathrm{~kg}$ bungkil kelapa pada induk yang sedang laktasi ternyata mampu meningkatkan produksi susu menjadi 1,05 1/ekor/hari (WIRDAHAYATI, 2005). Melalui penyuluhan, kami menawarkan beberapa pakan tambahan untuk konsentrat seperti sagu, dedak padi atau bungkil kelapa. Selanjutnya dalam hal sanitasi kandang, melalui penyuluhan kami menekankan pada peternak bahwa sanitasi kandang dan lingkungannya harus juga menjadi perhatian peternak, karena produksi susu mudah menyerap bau dan rusak. Cara beternak pada umumnya masih bersifat tradisional sehingga peternak perlu dibekali pengetahuan tentang sanitasi kandang dan peralatan pemerahan, yaitu peternak harus memperhatikan peralatan penampungan susu, tempat pakan dan tempat minum dengan benar. Materi ini disampaikan oleh ibu Prof. Salam Aritonang dan Dr. Ir. Elly Roza, MP.

\section{Dadih dan Manfaatnya}

Materi ini disampaikan oleh Prof. Salam Aritonang, beliau menjelaskan tentang profil dan keberadaan dadih saat ini. Dibandingkan dengan yoghurt keberadaan dadih relatif belum dikenal masyarakat. Hal ini kemungkinan karena adanya anggapan bahwa dadih harus terbuat dari susu kerbau di dalam bambu, sehingga sulit untuk dikembangkan dalam skala yang lebih besar. Dadih memiliki tekstur padat, dengan kadar keasaman $(\mathrm{pH})$ sekitar 3,4. Karakteristik dadih susu kerbau adalah sebagai berikut: kadar air (84,35\%), protein (5,93\%), lemak (5,42\%), karbohidrat $(3,34 \%)$. Komposisi gizi akan sangat tergantung dari kualitas susu yang digunakan.

Saat ini pengolahan dadih masih dikerjakan oleh industri rumah tangga pangan (IRTP). Penyebarannya juga masih sangat terbatas yaitu di propinsi Sumatera Barat terutama di daerah Bukit Tinggi, Agam , Payakumbuh dan di propinsi Riau. Belum berkembangnya industri pengolahan dadih di Indonesia kemungkinan dikarenakan beberapa faktor antara lain: (i) bahan baku susu kerbau, (ii) penggunaan bambu dan (iii) tidak tersedianya kultur untuk starter dadih. Sampai saat ini pembuatan dadih ditingkat peternak dilakukan secara tradisional dan belum ada standar cara pembuatannya . Oleh sebab itu dadih yang dihasilkan dari tiap daerah bervariasi mutunya .

Namun sebagai produk susu yang difermentasi bakteri asam laktat manfaat dadih lebih dari sekedar makanan. Bakteri asam laktat sudah digunakan sejak lama pada produk-produk susu dan efek imunitasnya menjadikan produk ini berguna untuk kesehatan manusia. Bakteri asam laktat dapat berasal dari saluran pencernaan manusia, produk-produk susu dan secara alamiah terdapat juga pada tanaman tertentu . Beberapa 
species digunakan secara komersiat untuk memproduksi susu fermentasi dan produk daging . sebagai produk pangan fungsional ( Esti Widjayanti dkk., 2004) yaitu pangan yang karenakandungan komponen aktifnya dapat memberikan manfaat bagi kesehatan, diluar manfaat yang diberikan oleh zat-zat gizi yang terkandunga didalamnya.

\section{Penyuluhan Tentang Diversifikasi Dadih Menjadi Produk Lain dan Penghitungan Nilai Tambah.}

Berdasarkan referensi olahan dadih dari Labor Tekhnologi Hasil Ternak Fakultas Peternakan Universitas Andalas, tim memberikan beberapa olahan dadih seperti es dadih, pudding dadih dan permen dadih. Kegiatan penyuluhan dan pelatihan pembuatan olahan dadih ini dihadiri oleh semua anggota kelompok. Pada Umumnya anggota kelompok dan keluarganya terutama anak-anak tidak menyukai dadih. Setelah tim menjelaskan beberapa metoda olahan dadih dan manfaat dadih, semua anggota menyukai olahan dadih ini. Metoda pengolahan yang sederhana dengan bahan baku yang mudah dijumpai di sekitar mereka membuat anggota sangat antusias mencobanya, apalagi setelah dijelaskan besarnya pendapatan yang mereka peroleh dari olahan dadih ini. Berikut ini analisa nilai tambah dari beberapa produk olahan yang kami hitung:

\section{Es dadih}

Rata-rata jumlah es yang dihasilkan dari 10 tabung dadih adalah sebesar 200 bungkus. Nilai tambah yang diperoleh dari pengolahan 10 tabung dadih menjadi es adalah Rp. 114.236,-. Atau nilai tambah per bahan baku yang digunakan sebesar Rp $11.423,-/ 1$ tabung dadih dengan Rasio nilai tambah yang diperoleh adalah $60.86 \%$. Hal ini berarti, dalam pengolahan dadih menjadi es dadih memberikan nilai tambah sebesar $60.86 \%$ dari nilai produk. Jadi jika peternak menjual dadih/tabungnya hanya Rp.4.000,-, maka dengan mengolah dadih menjadi es ini bisa meningkatkan pendapatan menjadi Rp.11.423,-/tabung.

\section{Pudding Dadih}

Rata-rata jumlah output yang dihasilkan adalah sebesar 120 cup ( $150 \mathrm{ml}$ ), dengan mengolah dadih sebanyak 10 tabung. Nilai tambah yang diperoleh dari pengolahan 10 tabung dadih menjadi pudding dadih adalah Rp. 236.800,-. Atau nilai tambah per bahan baku yang digunakan sebesar Rp 23.680,-/1 tabung dadih dengan rasio nilai tambah yang diperoleh adalah $66 \%$. Hal ini berarti, dalam pengolahan dadih menjadi pudding memberikan nilai tambah sebesar $66 \%$ dari nilai produk.Dan keuntungan yang diperoleh sebesar Rp.236.738,-.

\section{Jus Dadih}

Berbeda halnya dengan pengolahan dadih menjadi jus dadih, dimana rata-rata jumlah output yang dihasilkan adalah sebesar 40 gelas ( $250 \mathrm{ml} /$ gelas $)$,dengan mengolah dadih sebanyak 10 tabung. Nilai tambah yang diperoleh dari pengolahan 10 tabung dadih menjadi jus dadih adalah Rp. 223.800,-, atau nilai tambah per bahan baku yang digunakan sebesar $\mathrm{Rp} 22.380,-/ 1$ tabung dadih dengan rasio nilai tambah yang diperoleh adalah $70 \%$. Hal ini berarti, dalam pengolahan dadih menjadi jus memberikan nilai tambah sebesar 70\% dari nilai produk.Dan keuntungan yang diperoleh sebesar Rp. 223.738,-. Dari paparan analisa ekonomi ini, anggota kelompok sangat antusias melakukan usaha diversifikasi ini, ditambah lagi bahwa setelah dilakukan penyuluhan dan sosialisasi di sekolah-sekolah tentang manfaat dadih serta rasa olahan dadih, anak- 
anak sekolah sangat menyukai produk ini. Materi ini diberikan oleh Ir.Amna Suresti, M.Si.

\section{Perbaikan Kemasan}

Salah satu faktor yang dapat menarik perhatian konsumen dan mempengaruhi secara langsung proses pembelian adalah kemasan. Kemasan merupakan salah satu strategi dalam bauran pemasaran. Perkembangan kecil pada kemasan atau penampakan luar dari sebuah produk dapat memberikan reaksi yang sangat berbeda dari konsumen.

Untuk olahan dadih berupa pudding, kami memberikan cup plastic yang telah dilengkapi dengan labeling. Sementara ini labling yang kami rancang berupa kertas stiker yang dicetak sesuai keinginan dan kebutuhan mitra.

\section{Kegiatan Perbaikan Pemasaran}

Selama kegiatan berlangsung, kelompok usaha bisnis telah didorong untuk mulai membuka diri untuk melakukan promosi lebih intensif dengan mengembangkan media promosi seperti brosur yang disebarkan kepada target pelanggan seperti instansi, sekolah.. Dari diskusi disarankan kepada pemilik untuk memberikan identitas pada produk yang dijual, sehingga konsumen dapat dengan mudah mengenali produk yang dihasilkan mitra.

Untuk memperluas pasar olahan dadih ini, kami telah melakukan sosialisasi di sekolah- sekolah tentang manfaat dadih serta memberikan beberapa olahan dadih ini secara gratis kepada anak-anak tersebut. Tanggapan mereka sangat senang, karena mereka selama ini tidak mau makan dadih karena rasa dan aromanya tidak disukai. Disamping itu, kami juga telah menyebarkan brosur-brosur ke masyarakat setempat tentang dadih ini.

Untuk mengatasi masalah keterbatasan peternak untuk usaha minuman dan makanan dari dadih ini, kami juga memberikan 2 unit kulkas dan 2 unit blender serta 1 unit etalase tempat penyimpanan produk.

\section{Kegiatan Pembinaan}

Pemantauan terhadap mitra dilakukan secara berkala dalam hal peremajaan stater yoghurt, manajemen pemeliharaan sapi perah, dan recording usaha ternak sapi perah. Selain itu juga dilakukan pemantauan dalam proses produksi dan pemasaran produk olahan susu sapi perah mitra. Setelah kegiatan ini selesai, pemantauan tetap dilakukan secara berkala.

\section{KESIMPULAN}

Berdasarkan kegiatan yang telah dilaksanakan maka dapat disimpulkan yaitu: 1 . Kegiatan pelatihan motivasi wirausaha mampu meningkatkan jiwa entrepreneurship para produsen dadih sebagai upaya menunjang kegiatan pengembangan kelompok usaha, 2. Kegiatan penyuluhan manajemen pemeliharaan ternak kerbau mampu meningkatkan wawasan dan pengetahuan peternak dalam memelihara ternak kerbau, 3 . Pelatihan dan percontohan diversifikasi dadih mampu meningkatkan pendapatan, dan 4 . Kegiatan promosi dan pengembangan jaringan pemasaran telah dijadikan sebagai strategi pemasaran untuk meningkatkan volume produksi kelompok usaha. 


\section{DAFTAR PUSTAKA}

Akuzawa R and I.S. Surono. 2002. Fermented Milks of Asia. In: Roginski H, Fuquay J.W, Fox PF, editors. Encyclopedia of dairy sciences. Academic Press Ltd, London (UK).

Anoraga dan Pandji. 2007. Pengantar Bisnis. Pengelolaan Bisnis Dalam Era. Globalisasi, Jakarta.

Assauri, S.1990. Manajemen Pemasaran: Dasar, Konsep dan Strategi. Rajawali Press, Jakarta.

McCharty, J and W. D. Pereault. 1990. Basic, Marketing. Richard D. Irwin. Inc, USA.

Putra A.A., Mardila Y, Khasrad, S.Y.D. Azhike, dan R. Wulandari. 2011. Perkembangan dan usaha pengembangan dadih: sebuah review tentang susu fermentasi tradisional Minangkabau. J Peternakan Indonesia. 13:159-170.

Rizqiati H, Sumantri C, R.R. Noor, E. Damayanthi, dan E. Rianti. 2015. Isolation and identification of indigenous lactic acid bacteria from North Sumatera River Buffalo Milk. IJAVS. 20: 87-94.

Siagian.S. 1998. Managemen Strategi. Bumi Aksara, Jakarta.

Sirait, C.H., H . Setiyanto, Triyantini dan R. Sunarlim .1994. Evaluasi mutu dadih . Prosiding Seminar Sain dan Teknologi Peternakan. Ciawi-Bogor 25-26 Januari 1994. Hal: 275-280.

Standar Nasional Indonesia (SNI). 1998. Badan Standarisasi Nasional. BSN, Jakarta.

Sughita dan I. Made. 1998. Teknologi Pembuatan Dadih. Fakultas Peternakan Universitas Andalas, Padang. 